\title{
Avian IgY antibodies, ancestors of mammalian antibodies - production and application
}

\author{
ADRIANA CRISTE ${ }^{1 *}$, ADRIANA CRISTINA URCAN ${ }^{1}$, NICOLAE CORCIONIVOSCHI ${ }^{2}$ \\ ${ }^{1}$ Department of Microbiology and Immunology, University of Agricultural Sciences and Veterinary \\ Medicine, Faculty of Animal Science and Biotechnologies, Cluj-Napoca, Romania \\ ${ }^{2}$ Agri-Food and Biosciences Institute, Bacteriology Branch, Belfast, United Kingdom
}

\begin{abstract}
As mammals provide passive trans-placental immunity to the fetus, a similar mechanism is recorded in poultry, where immunity comes from egg fluids and is called vitelline immunity. In poultry, while the egg is in the ovary, the serum immunoglobulin $\mathrm{Y}$ is transferred in the egg yolk, and during the passage of the egg through oviduct, the immunoglobulins $\operatorname{IgM}$ and $\operatorname{IgA}$ were transferred in the albumen along with the secretions of the oviduct. Due to the phylogenetic distance between birds and mammals, chicken antibodies have clear advantages over mammalian immunoglobulins. Due to the direct transfer from serum to the follicle, the amount of IgY is huge. From a single yolk can isolate between 100 and $400 \mathrm{mg} \mathrm{IgY}$. In addition to the quantitative advantage of $\operatorname{IgY}$ production, there is also the qualitative advantage of low contamination, the production is non-invasive and IgY antibodies can be used in immunodiagnosis, immunoprophylaxy and immunotherapy.
\end{abstract}

Keywords IgY antibodies, Immunodiagnosis, Immunoprophylaxy, Immunotherapy.

To cite this article: CRISTE A, URCAN AC, CORCIONIVOSCHI N. Avian IgY antibodies, ancestors of mammalian antibodies - production and application. Rom Biotechnol Lett. 2020; 25(2): 1311-1319. DOI: 10.25083/rb1/25.2/1311.1319

*Corresponding author: ADRIANA CRISTE, Department of Microbiology and Immunology, University of Agricultural Sciences and Veterinary Medicine, Faculty of Animal Science and Biotechnologies, 3-5 Mănăştur Street, Cluj-Napoca 400372, Romania E-mail: adriana.criste@ usamvcluj.ro 


\section{Introduction}

Immunoglobulin $\mathrm{Y}$ is a type of immunoglobulin that is the primary antibody in birds and is also found in high concentrations in egg yolk. Immunoglobulin Y from serum is transferred in yolk and $\operatorname{IgM}$ and $\operatorname{IgA}$ in egg whites. Regarding the ovarian transfer of IgY, it is performed over a period of 5 days. There was a correspondence between serum and vitelline levels of $\mathrm{IgY}$, if we consider the time interval required for the passage. Transfer is not selective, so serum antibody concentrations can be found when testing on ovarian extracts or with whole-egg immunoglobulin.

From a single yolk can isolate between 100 and $400 \mathrm{mg}$ IgY, which represents in the range of at least $1500 \mathrm{mg}$ IgY / bird, antibodies with an IgY specificity between 2 and $10 \%$ (SCHADE \& al [1]), whereas about $200 \mathrm{mg}$ of IgG can be isolated monthly from rabbits with $5 \%$ specific antibodies. In addition to the quantitative advantage of IgY production, there is also the qualitative advantage, namely the low contamination of these antibodies, relative to other antibodies or antibody fragments from natural or recombinant sources. The production of this immunoglobulin, tis noninvasive and the use of IgY antibodies also presents specific advantages: IgY avoids complement activation, IgY avoids interaction with rheumatoid factor $(\mathrm{RF})$ and human antimouse IgG (HAMA) antibodies (CARLANDER \& al [2]), IgY avian antibodies do not react with proteins $A$ or $G$, which can be used to reduce the interference problems caused by Fc receptors for bacteria in immunological analyzes (FISCHER \& al [3]).

\section{Avian immune system}

The ontogenetic development of the immune system in birds has been widely researched and discussed in order to establish how these animals with a special structure of the lymphatic system develop their immunobiological mechanisms. Like the mammalian immune system, the bird's immune system is divided into two main components: non-specific (inherited) immunity and specific (acquired) immunity. There are numerous very important interactions between the two components in the immune response (SCHADE \& al [1]).

\section{Natural immunity}

Nonspecific, natural immunity includes mechanisms born or inherited by which birds defend against diseases. This resistance manifests itself against different infectious factors and is achieved through normal structures and functions of the body (CARLANDER \& al [2]).

Therefore, the natural resistance results from the passive interposition of some anatomical structures and from the active intervention of some humoral factors. This type of resistance characteristic of a species defines the resistance capacity of all individuals of the respective species, against some microorganisms, which for other species may be pathogenic. The mechanisms that ensure the innate resistance are the most efficient, giving all individuals of a species an almost absolute resistance to a very wide range of agents of aggression. The defense factors are considered non-specific, because they are active against any aggression agent, against which the respective species has resistance (MILLET \& al [4]).

Although the factors of natural resistance are the same in all species, the resistance capacity manifests itself differently from different microbial agents (CRISTE \& al [5]).

The factors that ensure the natural resistance are classified as follows: passive factors and cellular factors.

Passive factors of natural resistance are represented by genetic factors, body temperature, normal (resident) microflora, and various structures such as skin and mucous membranes or the presence of airways in the respiratory tract (DAVISON \& al [6]).

Genetic factors: birds have certain receptors for certain microorganisms, the others, in the absence of specific receptors unable to infect the body. This mechanism is genetically determined and will be inherited by all descendants (SCHADE \& al [1]).

Body temperature: Birds have a higher normal body temperature than mammals, which prevents many diseases. This is due to the fact that many pathogenic microorganisms have an optimal development temperature at $35-37^{\circ} \mathrm{C}$, a temperature that is close to the maximum development temperature. Higher temperatures, therefore, optimum temperature for the development of microorganisms either do not allow their development or are even lethal to microorganisms. Therefore, the body temperature specifies the birds, does not allow the development and multiplication of numerous microorganisms (DAVISON \& al [6]).

Skin and mucous membranes: the skin-mucous coating, intact anatomically and functionally, represents the primary barrier through which organisms oppose the penetration of microorganisms in tissues and moods. The stratified, paved and cylindrical epithelia, composed of layers of compact cells adjacent, without intercellular spaces, provide a continuous coating, impervious to most microorganisms. The skin-mucous shell is the border between the sterile internal environment and the external environment polluted with microorganisms. In the case of nutritional deficiencies, especially biotin, or in the case of infectious diseases, the integrity of the skin can be compromised which allows its penetration by microorganisms (DAVISON \& al [6]).

Resident microflora: it manifests itself strongly in the skin and intestine. The presence of these germs greatly limits the multiplication of microorganisms with potential pathogen, by the production of inhibitors such as hydrogen peroxide, lactic acid, butyric and propionic acid, by the production of bacteriocins or antibiotics. In the case of antibiotics or in poor feeding and microclimate conditions, favorable conditions are created for the change the numerical relationships between resident and potentially pathogenic flora, so that in the absence of inhibitory factors secreted by the resident flora, the pathogenic flora will be able to colonize and cause disease (SCHADE \& al [1]). 
Respiratory cilia: In the respiratory tract the vibrating cilia along with the mucus are a real barrier against microbes. Thus, in the presence of mucus, the microbes are fixed, and this mucus loaded with microorganisms is eliminated by the movement of vibrating cells $(1-3 \mathrm{~cm} / \mathrm{h})$ (CARLANDER \& al [2]).

Active factors of the natural resistance are represented by molecular elements, present in humors, constituting the so-called humoral factors, and cellular elements with incorporation functions, forming cellular factors (DAVISON \& al [6]).

Active humoral factors are present in blood, lymph, joint fluid and various secretions, an important role having lysozyme, properdin and complement:

Lysozyme is a cationic enzyme, produced by macrophages, with mucolytic action, at $\mathrm{pH} 7$, which exerts a lithic action on some saprophytic or pathogenic microbes, especially Gram-positive ones. As a mechanism of action, lysozyme causes depolymerization and hydrolysis of mucopolysaccharides in the cell wall. It also contributes to complement fixation and facilitates phagocytosis (FISCHER \& al [3]).

Properdine is a glycoprotein, which acts synergistically with the complement, having an antibacterial effect against many germs, especially Gram-negative ones, also has antiviral activity (bacteriophage) and anticancer action (MILLET \& al [4]).

Complement (alexine) is a protein complex, synthesized by various cells and tissues in the body, even during the development of the embryo. The complement intervenes in the anti-infectious defense, contributing to the induction of the lysis phenomenon, potentiates phagocytosis by being involved in the processes of opsonization, immunoadhesion, cytotoxicity, bacteriolysis and cytolysis, and also in anaphylactic shock. Complement activity is regulated by homeostatic mechanisms, via serum inhibitors, while maintaining the complement title within certain limits. The intervention of the complement is conditioned by the presence on the immune effectors, of some coupling sites for the complement (receptors for the complement) (CRISTE \& al [5]).

Active cellular factors are of particular importance in the non-specific defense of the body against infections. They intervene in the defense processes by phagocytosis and pinocytosis, followed by the release of lithic enzymes, which cause the destruction of microorganisms. Phagocytes and the phagocytic system were first studied by Metchnikoff (1892). It classifies phagocytic cells into macrophages (large phagocytes) and microphages or granulocytes (small phagocytes or polymorphonuclear cells). From the immunological point of view, these two categories are essentially distinguished by phagocytic kinetics, the granulocytes completely degrading the antigens, while the macrophage digestion preserves the degraded parts of the molecule containing the antigenic determinants. Thus, in the realization of phagocytosis, cells with properties of capture, incorporation and digestion of germs, belonging to the large group of white blood cells (white blood cells). Mononuclear (lymphocyte, monocyte) and polymorphonuclear (neutrophil, acidophil, basophil) leukocytes are strictly functional cells present in three compartments: hematoformator, blood (plasma), lax connective tissue (GEISSMANN \& al [7]).

\section{Acquired immunity}

Specific (acquired) immunity represents a superior form of anti-infectious resistance that is achieved through neoformation structures and functions, with a high degree of specificity. Active acquired immunity can have a natural or artificial mechanism of production and is called active because the body is actively involved in the production of immune effector. Naturally acquired immunity is also called post-infectious and occurs as a result of passing through the body through a disease (only after certain diseases). As a result of such a conflict between a microorganism and the higher organism, the latter gains a specific, strong resistance, sometimes for life. The immunity acquired artificially active is also called post-vaccine and is obtained following the administration of vaccines. This form of immunity occurs within 7-14 days of contact with the antigen or its inoculation, which is a time required for the production of immune effector. It lasts from 3-6 months, up to a year, rarely longer (CRISTE et al [8]).

Passive acquired immunity is the immunity obtained from the transfer of immune effectors (antibodies or immunocompetent cells) from a donor. It is called passive because the immunized organism receives the immune effectors produced by another organism; it does not intervene in their production, remaining passive from this point of view (MILLET\& al [4]).

Artificially acquired passive immunity performed following the administration of immune sera (serum) containing antibodies to a particular antigen. The induced immunization is strictly specific and is only effective against the antigen that was the basis of the formation of specific antibodies. Following administration of an immune serum, the immunity settles in a few hours, up to 24 hours, and lasts from a few days to 2-3 weeks. The administered antibodies are considered non-self, so they are gradually eliminated from the body, which explains the short duration of passive immunity (CRISTE \& al [5]).

Naturally passive acquired immunity is also called maternal or vitellin immunity in birds. As mammals provide the fetus with transplacental passive immunity, there is a similar mechanism in birds, the immunity from egg fluids to birds. When the egg is still in the ovary, the birds transfer the immunoglogulins $\mathrm{Y}$ from the serum to the egg yolk (egg), and when the egg passes through the oviduct the $\operatorname{IgM}$ and $\operatorname{IgA}$ immunoglobulins pass into the egg along with the oviduct secretions (CRISTE et al [8]).

Regarding the ovarian transfer of IgY, this is done within a period of about 5 days. There is a correlation between serum and vitreous levels of $\operatorname{IgY}$ if the time interval required for passage is taken into account. Transfer is not selective, so that serum concentrations of antibodies can be recovered and when tests are performed on ovulating 
immunoglobulin extracts or whole yolk. IgY access to the embryos is a two-way process. In a first stage $\operatorname{IgY}$ passes from the serum level into the ovarian follicles through an active receptor-mediated process, analogous to transplacental transfer in mammals. Subsequently from the level the vitreous sac of the immunoglobulin reaches the tissues of the embryo also through receptor-mediated transport. Vitellus resorption begins at 24 hours post-exclusion, and the deficiencies associated with this process impede the transfer of maternal immunity and implicitly the resistance to pathogens during the neo-natal period. IgY also provides nutritional support for embryo development. The serum level of $\operatorname{IgY}$ in chickens in the immediate post-eclectic period does not exceed $1-1.5 \mathrm{mg} / \mathrm{ml}$. Given that the vitellus contains appreciable amounts of immunoglobulin (between 100 and $400 \mathrm{mg}$ ) it is easy to deduce that much of the ovular IgY is the nutritional source for the developing embryo. Therefore, vitelline immunity is the immunity transmitted by the birds through the egg and which ensures the protection of the chicks immediately after hatching (CRISTE \& al [9]).

\section{Immunoglobulin classes}

In birds, the Fabricius bursa is an essential organ for the development of lymphatic cells in birds, the organ in which B lymphocytes synthesize and secrete immunoglobulins (RATCLIFFE \& al [10]). In the serum of the birds there are three classes of immunoglobulins, distinct antigenically, of which two $\operatorname{IgM}$ and $\operatorname{IgA}$ are common to mammals (CARLANDER \& al [11]), while the third class IgY differs from the one present in mammals (IgG). Antibodies belonging to $\operatorname{IgE}$ and $\operatorname{IgD}$ classes have been reported to be present in some studies but have not been documented so far (CHEN \& al [12]) as opposed to mammals, in no species of Aves class minor subtypes or structural variations were detected within an immunoglobulin isotype (RATCLIFFE \& al [13]).

If structurally $\operatorname{IgY}$ is a monomer, $\operatorname{IgM}$ is pentameric, whereas IgA exists both as a monomer but predominates as a polymer (WERNER \& al [14]). Each type of immunoglobulin appears at different stages of development in the ontogeny of the embryo: the order of appearance of the immunoglobulins is the following $\operatorname{IgM}$, $\operatorname{IgY}$ and $\operatorname{IgA}$. $\operatorname{IgM}$ present in birds has the same functions as that found in mammals, being the most widespread immunoglobulin, having a high capacity for agglutination, opsonization and lysis and also intervenes in complement activation in the alternative pathway. This type of $\mathrm{Ig}$ has no reactive activity and does not attach to mast cells or monocytes. IgM is the first class of antibodies that is present after immunization, so it intervenes in the primary immune response being detectable at 4-5 days after immunization, with a maximum titer at 5-6 days, after 10-12 days their concentration decreases massively. Regarding IgA, it is detected after 5 days of immunization and does not show significant differences from the IgA house found in mammals, being present in both serum and secretions (serum $\operatorname{IgA}$ and secretory $\operatorname{Ig} \mathrm{A}$ ), having an intense bactericidal capacity, but it cannot agglutinate, precipitate or lyse corpuscular antigens. Avian immunoglobulin $\mathrm{A}$ is therefore mainly involved in the protection of epithelia and mucous membranes, as well as mammalian IgA, this avian isotype can be detected at serum level from day 10 post-eclossion, but it has also been detected in the gallbladder or in various secretions.

$\mathrm{IgY}$ is the predominant class of immunoglobulins in birds, observed since 1969 by Leslie and Clem, being similar to the mammalian IgG class. This class was cataloged after genetic research, as the evolutionary precursor of modern antibodies, namely mammalian IgG and IgE (ROSE \& al [15]) and is detectable after 5 days from immunization, with maximum level at three weeks, after which it decreases slightly. Antibodies with IgY structure can be detected systemically; its presence in the duodenal content, the tracheal lavage and the seminal fluid also confer the attribute of a secretory immunoglobulin (CARLANDER \& al [11]).

Thus, IgY, like mammalian IgG, intervenes in the secondary immune response, being synthesized after $\operatorname{IgM}$, is predominant in the middle and late stages of the immune response. It plays a role in neutralizing toxins, viruses, bacteria, interferes with opsonic phagocytosis, antibodydependent cytotoxicity and complement activation. Following the analysis of the sequence of DNA sequences at the BCR locus, it is observed that they are more similar to those encoding $\operatorname{IgE}$ than $\operatorname{IgG}$, which may be associated with the involvement of $\operatorname{IgY}$ in anaphylactic reactions. Also $\mathrm{IgY}$ is also a skin sensitizing antibody function attributed to immunoglobulins $\mathrm{E}$ in mammals, IgY, combining functions attributed to IgG and IgE in mammals. In egg, IgY is detected only at the vitelline level and plays a major role in the transfer of immunity (ROSE \& al [16]).

Passive immunization of offspring by means of maternal antibodies transferred from serum to vitellus has long been documented, by demonstrating the transmission of resistance to tetanus toxin from chickens to chickens. There are differences in IgY half-life in chicks compared to adult birds (WERNER \& al [14]). In chickens, the persistence is longer, the time interval in which the immunoglobulin can be detected is double compared to the adults. This aspect correlates with the time required to absorb the vitellus. In chickens, the half-life of serum IgY antibodies is 36 hours, much lower compared to that reported for small ruminants (15 days) and mammals in general (WOOLLEY \& al [17], ABBAS \& al [18]). The high catabolic rate in adults probably prevents the accumulation of very high levels of antibodies. It should be noted in this context that the avidity of avian antibodies is comparable to that of mammalian antibodies (WOOLLEY $\&$ al [17]).

In the anseriform birds (geese and ducks), however, a form of $\mathrm{IgY}$ with a molecular mass of $120 \mathrm{kDa}$ was observed, this being a truncated immunoglobulin $(\Delta \mathrm{Fc})$ that lacks the C3-C4 terminal domains, whereas in hens molecules are identified. IgY integrates. Structurally, there are clear differences between $\operatorname{IgY}$ and $\operatorname{IgG}$ in both the heavy chains and the hinge region. The molecular weight 
of $\operatorname{IgY}$ is $167,259 \mathrm{kDa}$ slightly higher in mammalian $\mathrm{IgG}$ ( $160 \mathrm{kDa})$ (SUN \& al [19]), having four constant regions (five domains: four constants and one variable), as opposed to three each. IgG in mammals. This additional immunoglobulin domain is also distinct from the mammalian antigenic point of view.

The transfer of the three classes of immunoglobulins in the eggs of the birds is accomplished by multiple mechanisms. IgA and IgM are transferred together in the white. On the other hand, IgY from the egg follicles is only passed through the receptors and hence selectively, in large quantities, into the yolk. The concentration of $\operatorname{IgY}$ in the yolk is $10-20 \mathrm{mg} / \mathrm{ml} \mathrm{IgY,} \mathrm{so} \mathrm{about} 100-400 \mathrm{mg} \operatorname{IgY}$ is obtained from an egg. Transovarian passage lasts approximately 5 days (PATTERON \& al [20], WEIGLE \& al [21]). The $\operatorname{IgY}$ content in both serum and yolk is positively correlated, and if passage time is taken into account, antibody titers after immunization can be determined directly from yolk. The amount of IgY transferred is independent of the egg size but is proportional to the concentration of IgY in the mother serum. The total amount of IgY present in hatched chicks is $2-3 \mathrm{mg}$, compared to $100-400 \mathrm{mg}$ present in yolk. It is assumed that much of this quantity is used as nutrient by the developing embryo (CARLANDER \& al [2]). What is important to note is that a large amount of antibodies specific for secondary immune response (IgY) can be isolated from yolk without impurities represented by $\operatorname{IgM}$ or $\operatorname{IgA}$.

IgY molecules have slightly reduced stability at acidic $\mathrm{pH}$ compared to bovine Ig and have a lower resistance to digestion with pepsin (SHIMIZU \& al [22]). Trypsin and chymotrypsin proteases do not destabilize the avian monomer. Even the presence of IgY-like molecules resistant to papain digestion has been reported (LOEKEN $\&$ al [23]). The activity of antibodies with IgY structure is affected by physical and chemical factors. The protein structure of IgY imprints sensitivity to distortion. It should be noted, however, that maintaining for 15 minutes at $70^{\circ} \mathrm{C}$ does not affect the stability of the molecule. Also, incubation at $37^{\circ} \mathrm{C}$ in a medium with a $\mathrm{pH}$ greater than 4 does not reduce antibody activity, while increased acidity ( $\mathrm{pH}$ below 2 ) induces irreversible conformational changes (SHIMIZU \& al [24]). Pasteurization at $60^{\circ} \mathrm{C}$ for 3 minute does not alter the reactivity of antibodies with IgY structure (YAMMAMOTO \& al [25]).

Stabilization of the molecule against heat (denaturation), acidic medium or high pressure can be achieved by the addition of sucrose (SHIMIZU \& al [24]). The stability of $\operatorname{IgY}$ at long-term maintenance, by refrigeration with or without the addition of preservatives, or at ambient temperature is remarkable (SCHADE \& al [26]). Antibodies with IgY structure can be conserved for similar periods of time to those reported for mammalian antibodies. IgY as well as mammalian $\operatorname{IgG}$ is the predominant serum isotype in the secondary immune response. Most effector IgY functions in chickens, such as complement fixation and opsonization, are mediated by the $\mathrm{Fc}$ region belonging to IgY. Unlike mammalian monomer,
$\operatorname{IgY}$ also appears to be involved in anaphylactic reactions (ROSE \& al [15]).

In the body, the immunoglobulin molecules can be free (in biological fluids, tissues or epithelia), coupled with the inducing antigen in the form of immune complexes, molecules attached to various cells or tissues and molecules anchored in B-cell plasmid, having the role of antigen receptors. In birds, immunoglobulins can be detected in larger quantities and in egg yolk, correlated with the physiology of these animals (CARLANDER \& al [2]). The transfer of the three isotypes at the egg level is done through different mechanisms and pathways (ROSE \& al [16]). IgA and $\operatorname{IgM}$ together with other proteins are incorporated into the egg yolk at the oviduct level. However, the quantities transferred are very reduce $(\mu \mathrm{g})$. $\operatorname{Ig} \mathrm{Y}$ is present at the vitelline level in relatively constant concentration throughout the maturation of the ovarian follicle.

\section{Advantages of using avian antibodies}

Avian antibodies are increasingly being used in fundamental research. Due to the phylogenetic distance between birds and mammals, chicken antibodies in particular have clear advantages over mammalian immunoglobulins. First of all, mammalian antigens will be immediately recognized as foreign. Then, following administration of antisera, several mammalian antigen epitopes can be recognized by the antibodies of birds. Due to the direct transfer from the serum into the follicle, the amount of IgY is huge. From a single yolk can isolate between 100 and $400 \mathrm{mg} \operatorname{IgY}$, which represents in the range of at least $1500 \mathrm{mg} \operatorname{IgY} /$ bird, antibodies with an $\operatorname{IgY}$ specificity between 2 and 10\% (SCHADE \& al [1]), whereas about $200 \mathrm{mg}$ of $\mathrm{IgG}$ can be isolated monthly from rabbits with $5 \%$ specific antibodies. In addition to the quantitative advantage of $\operatorname{IgY}$ production, there is also the qualitative advantage, namely the low contamination of these antibodies, relative to other antibodies or antibody fragments from natural or recombinant sources.

At the same time, the use of eggs and implicitly the chickens for obtaining antibodies is a non-invasive method because it does not involve the harvesting of blood and implicitly painful maneuvers. The only discomfort to birds is the immunization (present disadvantage in the case of immunization of other animals to obtain $\operatorname{IgG}$ ), but in order to obtain a prompt and lasting response, small amounts of antigen are needed (GASSMAN \& al [27]). Due to the effort to reduce and replace the exploitation of animals, the production of antibodies in the eggs of birds has increased attention. Therefore, immunoglobulins $\mathrm{Y}$ can be used in many immunological studies giving better results than the use of mammalian antibodies.

In addition to these advantages related to the production of this immunoglobulin, the use of IgY-type antibodies also presents specific advantages that recommend their use: $\operatorname{IgY}$ avoids complement activation, $\operatorname{IgY}$ avoids interaction with rheumatoid factor (RF) and human anti-mouse IgG (HAMA) antibodies (CARLANDER \& al 
[2]), IgY avian antibodies do not react with proteins A or $\mathrm{G}$, which can be used to reduce the interference problems caused by $\mathrm{Fc}$ receptors for bacteria in immunological analyzes (FISCHER \& al [3]).

Taking into account the IgY characteristics and the advantages mentioned above there is the possibility of using the avian monomer in various medical fields:

Research: Immunoglobulins are indispensable tools for studies aiming to characterize protein or peptide molecular structures. Immunization of birds with peptides has made it possible to obtain antibodies useful for research activity (SCHADE \& al [28]). These can be easily labeled and subsequently introduced into various investigation procedures. Avian antibodies directed to the expression products of separate genes are preferred in genomics and proteomics studies that aim to establish clear gene-peptide product interdependencies (ZHANG \& al [29]). In the case of immunoassays, homologous mammalian immunoglobulins may have deleterious effects on the performance of many different types of immunoassays. In particular, approaches using immunoglobulins as bioactive molecules to capture or detect the analyte are often affected by heterophilic antibodies and/or high levels of non-specific binding (SPILLNER \& al [30]). ELISA test using specific IgY was developed to detect the staphylococcal enterotoxin $\mathrm{G}$, from milk and dairy products samples and could therefore be used to identify the toxin in food (NAGARAJ \& al [31]).

Diagnosis: Most currently used immunotests are based on murine monoclonal antibodies, but recent research evidence the potential of the use of monoclonal $\mathrm{IgY}$ as a way of avoiding interference by rheumatoid factor and heterophilic antibodies in human serum samples (SPILLNER \& al [30]).

Immunoglobulins extracted from egg yolk are convenient alternatives in terms of quality, technology and costs for diagnostic reagents. Antibodies with IgY structure allow accurate identification and thus diagnosis by various serological tests of viral, bacterial and parasitic diseases, as well as in the identification and quantification of physiological or pathological protein structures (hormones, neoantigens, structural proteins, mammalian immunoglobulins, membrane receptors) (SCHADE \& al [28]). The absence of immunological cross-reactivity between chicken IgY and mammalian IgG determined by the evolutionary distance, reinforces the advantages of using IgY over IgG as the first antibody in some types of immunological reactions.

The use of a hyperimmunization protocol results in a high level of serum antibody and vitelline titers, which can be used in immunodiagnosis. Immunoglobulins isolated from egg it is find in high concentration comparative the serum, have a high resistance to temperature and $\mathrm{pH}$ and it is not interfere with mammalian antibodies. These advantages recommend use of obtained antibodies in different immune reactions for diagnosis of salmonellosis (CRISTE \& al [32], CRISTE \& al [33]).

IgY-based sandwich ELISA exhibited sensitivity and specificity of $93.3 \%$ and $76.7 \%$, respectively, in an investigation of 90 human cases positive or negative for opisthorchiasis (TEIMOORI \& al [34]). IgY antibodies from the egg yolks of hens that were immunized with the total antigenic extracts of Strongyloides venezuelensis infectious filariform larvae (iL3) and parthenogenetic females $(\mathrm{pF})$, used in immunodiagnosis showed diagnostic values for anti-iL3 IgY and anti-pF IgY antibodies at 95.56\% and $88.89 \%$ sensitivity and $95.56 \%$ and $91.11 \%$ specificity (DE FARIA \& al [35]).

Rabies virus-specific antibodies obtained by immunizing layer hens with recombinant rabies virus internal proteins expressed in Escherichia coli and obtain a nearly equivalent amount of specific antibody without euthanizing animals, by immunization of a hen instead of a rabbit. In this way, by combining the expression of rabies $\mathrm{N}$ or $\mathrm{P}$ protein and the immunization of hens, it will be possible to supply a plentiful amount of antibodies for easy and inexpensive diagnosis of rabies and these $\operatorname{IgY}$ antibodies could detect rabies virus antigen in the neurons of infected mice, immunohistochemical analysis of formalin-fixed mouse tissue infected with CVS-11 (MOTOI \& al [36]).

Therapy and prophylaxis: Currently ovular immunoglobulin concentrates are used for the prevention and control of bacterial and viral diseases. Today's consumers have become increasingly interested in foods that supposedly promote health and reduce the risk of disease.

Antibacterial activity: Used as an alternative to antibiotic therapy, IgY does not induce antimicrobial resistance and does not exhibit remanence in the treared organism (CHIURCIU \& al [37]). IgY-containing product, block bacterial adhesion factors, preventing colonization of the intestine. Numerous studies indicate the administration either in purified form (IgY extracted and lyophilized) or even in native (egg yolk) form of anti-ETEC antibodies (F4, F5, F6) in pigs and cattle mainly (ERHARD \& al [38]), anti-Yersinia ruckeri for the prevention of enteric trout disease(LEE \& al [39]), anti-Helicobacter pylori for the prevention of gastritis (MONY \& al [40]).

One of the most studied diagnostic potential of $\operatorname{IgY}$ is against Staphylococcus aureus, for the reason that the IgY don't reacts with the staphylococcal protein A and makes possible to detect different $S$. aureus strains and their toxins. Avian immunoglobulin formed immune support and can be used for MRSA infection (WALCZAK \& al [41]).

Salmonela enterica serovar gallinarum is the causative agent of typhoid fever, systemic disease of chickens that results in high mortality amongst infected flocks. The anti-Salmonella specific antibodies could be used in food and feedstuffs for the control of the salmonellosis, with large applications. Due to the agglutination carried out by the specific antibodies, the bacteria have a lower mobility and a reduced possibility to reach the nutrients which causes the inhibition of the bacteria multiplication. The addition of the specific antibodies inhibits the development of the Salmonella and reduces the risk of salmonellosis, if they are used as food or feed additives (CRISTE \& al [42]).

IgY raised against the bacterium Listeria monocytogenes showed a significant inhibitory effect of 
bacterial growth in liquid medium and in fish samples stored between 0 and $6^{\circ} \mathrm{C}$ in a dose-dependent manner, which indicates that anti-L. monocytogenes $\operatorname{IgY}$ is a potential antimicrobial for use in the food industry (SUI \& al [43]) .

Anti-Pseudomonas IgY was shown to bind the $P$. aeruginosa protein flagellin, which is the main component of the flagellum and is required for the motility and chemotaxis of the bacteria (HONKO \& al [44]). The biochemical properties of IgY confer resistance of the molecule to the digestive tract. Even if the cleavage occurs under pepsin action, the resulting fragments retain their blocking or neutralizing capacity (SCHIMAMOTO $\&$ al [45]). IgY does not induce inflammatory reactions in the intestine, as it does not activate the complement and does not interact with the Fc receptors present in the phagocytes (CARLANDER \& al [2]). The development of resistance factors to antibiotic therapy in many bacterial species with digestive tropism, but not only, also supports the use of IgY as a therapeutic alternative (CARLANDER [2], MINE \& al [46].

Antiviral activity: Substantial proportion of respiratory infections are acute viral infections. The management of such infections includes use of antivirals and treatment to relieve disease symptoms. However, most antiviral agents target conserved viral proteins, which places selective pressure on the virus, leading to the development of antiviral resistance (MC CASKILL \& al [47]). In vitro investigation of IgYs produced from hens immunized with inactivated $\mathrm{H} 1 \mathrm{~N} 1, \mathrm{H} 3 \mathrm{~N} 2$, and $\mathrm{H} 5 \mathrm{~N} 1$ influenza viruses showed that the IgYs that were produced inhibited homologous as well as heterologous influenza viral strains (WALLACH \& al [48]).

The development of high-titer anti-SARS coronavirus IgY (FU \& al [49]) have potential as a new anti-SARS biological product for passive immunization, as it effectively neutralized the SARS Coronavirus.

The use of egg yolk from birds hyperimmunized with BHV-1 antigens to condition bovine semen inactivates the virus, thus limiting the transmission of genital herpesvirus through artificial seeding (QUEIROZ-CASTRO \& al [50]).

Antifungal activity: Oral fungal infections have a long disease course, are not easily cleared, and are prone to relapse. Although most oral fungal infections are superficial, the number of deep infections, which can be life threatening, is on the rise. Candida albicans-specific chicken egg yolk antibody (IgY) inhibit of fluconazolesensitive and resistant strains of $C$. albicans and have a potential use in the prevention and treatment of oral candidiasis (WANG \& al [51]).

Antiparasitic activity: In 1985, Gottstein and Himmler employed IgY technology for the production of parasitespecific $\operatorname{IgY}$ as an alternative antibody in the serology of echinococcosis (GOTTSTEIN \& al [52]). Eggs from immunized hens were also used as a source of yolk antibodies directed against soluble proteins of Toxoplasma gondii (HASSL \& al [53]).

In 2012, Junior produced anti-T. gondii-IgY antibodies from hens immunized with soluble tachyzoite antigens of $T$. gondii (STAg) and demonstrated that anti- $T$. gondii-IgY showed an antigen recognition profile similar to mouse serum (JUNIOR \& al [54]). In 2014, Barenco et al reported the usage of IgY specific to the recombinant protein TgHSP70 (Toxoplasma gondii $70 \mathrm{kDa}$ Heat Shock Protein) in ELISA and immunohistochemistry (BARENCO \& al [55]) and $\mathrm{Xu}$ reported the dietary administration of specific IgY could provide partial protection against $E$. tenella challenge in newly hatched chicks (XU \& al [56]).

IgY against Trypanosoma evansi were used as a prophylactic drug (SAMPAIO \& al [57]) and antibodies for Trypanosoma cruzi trypomastigots produced in hens and that cross-reacted with $T$. evansi antigens were tested as a diagnostic tool (GRANDO \& al [58]).

Antivenom activity: Since 1894 the anti-venom serums were produced. The French pathologist, Dr. Albert Calmette was the first who demonstrated the venom protection in animals when immunization was performed with low venom doses were used. Calmette produced the first Naja kaouthia antiserum against venom in mule. In 1895 the first antiserum produced in equine saved several individuals with severe bites.

The results of investigations that followed the in vitro neutralizing efficacy of IgY against viper venom revealed superior biological activity of avian immunoglobulins compared with equine antiviperin serum (MAYA DEVY \& al [59]).

Different types of antivenin were produced using avian antibodies. In 2008, Criste demonstrated the activity of specific anti-venom using protection test in laboratory mice. The venom used for inoculation was harvested from two viper species (Vipera ammodytes and Vipera berus) (CRISTE \& al [60]).

Carlos Leónidas Leiva produced, characterized and assessed the efficacy of IgY-based antivenoms against Bothrops alternatus venom (LEIVA \& al [61]). Polyvalent anti-Bitis and anti-Naja antivenom IgY antibodies were also prepared using B. arietans, B. nasicornis, $B$. rhinoceros, $N$. melanoleuca, and $N$. mossambica venoms to immunize chickens (DE ALMEIDA \& al [62]).

IgY-technology may allow the production of effective and affordable antivenoms fulfilling the urgent needs of many countries where conventional manufacture is unable to provide enough availability of antivenoms.

\section{Conclusion}

The latest findings using IgY have clearly demonstrated the versatility of this technology. Obtaining IgY from birds presents several technical and economic advantages and IgY technology has a broad spectrum of applications in human and veterinary health. Avian immunoglobulin (IgY) therapy is an effective and safe alternative to classic treatment with synthetic antimicrobial agents, has no adverse effects, but has only one contraindication, that it is not administrated to patients with known allergy to the egg. 
In addition to the use of $\operatorname{IgY}$ antibodies in immunodiagnosis, incorporating egg yolks of immunized chickens into certain foodstuff, can provide the consumer with a functional food that can potentially protect against pathogens without consume synthetic pharmaceuticals. The therapeutic application is mainly reported for enteric zoopedriatic diseases with mono- or even polyfactorial etiology.

\section{References}

1. SCHADE R, HLINAK A, MARBURGER A, HENKLEIN $\mathrm{P}$ et al, Advantages of Using Egg Yolk Antibodies in the Life Sciences: The Results of Five Studies. ATLA Altern. to Lab. Anim. (1997).

2. CARLANDER D. Avian IgY Antibody - In vitro and in vivo, (2002).

3. FISCHER M, HLINAK A. The lack of binding ability of staphylococcal protein A and streptococcal protein $G$ to egg yolk immunoglobulins of different fowl species (short communication). Berl. Munch. Tierarztl. Wochenschr. (2000).

4. MILLET S, BENNETT J, LEE KA, HAU et al. Quantifying and comparing constitutive immunity across avian species. Dev. Comp. Immunol. (2007).

5. CRISTE A, particularities of poultry immune system compared to mammals. Bull. USAMV-Anim. Sci. Biotechnol. (2004), 60, 394.

6. DAVISON F, KASPERS B, SCHAT KA. Avian Immunology; Academic Press, ISBN: 9780080557595 (2008).

7. GEISSMANN F, JUNG S, LITTMAN DR. Blood monocytes consist of two principal subsets with distinct migratory properties. Immunity (2003).

8. CRISTE A, CUC C. Salmonella Gallinarum-Pullorum Antigen Stimulation for Antibody Production in Intensive Hens Raising System. Bull. USAMV-CN - V.M. 63, 90-95, (2008).

9. CRISTE A, PETRESCU I, CRISTE F. Eficiency of isolation techniques in quantitative obtaining of a $\mathrm{IgY}$. $41^{\text {st }}$ Croatian \& $1^{\text {st }}$ International symposium in agriculture, 13, Opatija - Croatia, p. 563 (2006).

10. RATCLIFFE MJ, LASSILA O, REYNOLDS J, PINK JR et al. A re-evaluation of the function of the bursa of Fabricius. Prog. Clin. Biol. Res. (1987).

11. CARLANDER D. Avian IgY Antibody; (2002); ISBN 9155452272

12. CHEN CL, LEHMEYER JE, COOPER MD Evidence for an $\mathrm{IgD}$ homologue on chicken lymphocytes. J. Immunol. (1982).

13. RATCLIFFE MJH. Antibodies, immunoglobulin genes and the bursa of Fabricius in chicken B cell development. Dev. Comp. Immunol. (2006).

14. WERNER LL. Laboratory Medicine - Avian and Exotic Pets. Vet. Clin. Pathol. (2001).

15. WARR GW, MAGOR KE, HIGGINS DA. IgY: clues to the origins of modern antibodies. Immunol. Today (1995).

16. ROSE ME, ORLANS E, BUTTRESS N. Immunoglobulin classes in the hen's egg: Their segregation in yolk and white. Eur. J. Immunol. (1974).
17. WOOLLEY JA, LANDON J. Comparison of antibody production to human interleukin-6 (IL-6) by sheep and chickens. J. Immunol. Methods (1995).

18. ABBAS ABUL ANDREW H. LICHTMAN SHIV PILLAI, Cellular and Molecular Immunology, $7^{\text {th }}$ Edition. Med. Sci. Sport. Exerc. (2012).

19. SUN S, MO W, JI Y, LIU S. Preparation and mass spectrometric study of egg yolk antibody (Igy) against rabies virus. Rapid Commun. Mass Spectrom. (2001).

20. PATTERSON R, YOUNGNER JS, WEIGLE WO, DIXON FJ. Antibody production and transfer to egg yolk in chickens. J. Immunol. (1962).

21. WEIGLE WO, DIXON FJ, PATTERSON R, YOUNGNER JS et al. Chickens Transfer to Egg Yolk in Antibody Production and transfer to egg yolk in chickens . J Immunol (2017).

22. SHIMIZU M, NAGASHIMA H, HASHIMOTO K. Comparative studies on molecular stability of immunoglobulin $\mathrm{G}$ from different species. Comp. Biochem. Physiol. - Part B Biochem. (1993).

23. LOEKEN MR, ROTH TF. Analysis of maternal $\mathrm{IgG}$ subpopulations which are transported into the chicken oocyte. Immunology (1983).

24. SHIMIZU M, NAGASHIMA H, HASHIMOTO K, SUZUKI T. Egg Yolk Antibody (Ig Y) Stability in Aqueous Solution with High Sugar Concentrations. J. Food Sci. (1994).

25. YAMAMOTO T, JUNEJA LR, HATTA H, KIM M. Hen Eggs: Their Basic and Applied Science; ISBN 00443026 (1997).

26. SCHADE R, CALZADO EG, SARMIENTO $R$, CHACANA PA et al. Chicken egg yolk antibodies (IgY-technology): A review of progress in production and use in research and human and veterinary medicine. ATLA Altern. to Lab. Anim. (2005).

27. GASSMANN M, THOMMES P, WEISER T. HUBSCHER U. Efficient production of chicken egg yolk antibodies against a conserved mammalian protein. FASEB J. (1990).

28. SCHADE R, BEHN I, ERHARD M, HLINAK A, STAAK C (Eds.). Chicken Egg Yolk Antibodies, Production and Application (2001).

29. ZHANG WW. The use of gene-specific IgY antibodies for drug target discovery. Drug Discov. Today (2003).

30. SPILLNER E, BRAREN I, GREUNKE K, SEISMANN $\mathrm{H}$ et al. Avian IgY antibodies and their recombinant equivalents in research, diagnostics and therapy. Biologicals (2012).

31. NAGARAJ S, RAMLAL S, KINGSTON J, BATRA HV. Development of IgY based sandwich ELISA for the detection of staphylococcal enterotoxin G (SEG), an egc toxin. Int. J. Food Microbiol. (2016).

32. CRISTE ADRIANA. Utilizarea anticorpilor policlonali IgY în reacţii de imunodiagnostic al salmonelozelor. Lucr. ştiinţifice Ser. Zooteh. Univ. Ştiinţe Agric. şi Med. Vet. „Ion Ionescu la Brad” Iaşi 2006, 49, 9-13.

33. CRISTE A. The use of the specific anti-salmonella polyclonal antibodies isolated from hen eggs, in salmonellosis prophylaxis, Scientific Papers Animal Science and Biotechnologies, 40(1), 73-78, 40, 73-78, (2007). 
34. TEIMOORI S, ARIMATSU Y, LAHA T, KAEWKES S, et al. Chicken IgY-based coproantigen capture ELISA for diagnosis of human opisthorchiasis. Parasitol. Int. (2017).

35. DE FARIA L.S, DE SOUZA DLN, RIBEIRO RP, DE SOUSA JEN et al. Highly specific and sensitive anti-Strongyloides venezuelensis IgY antibodies applied to the human strongyloidiasis immunodiagnosis. Parasitol. Int. (2019).

36. MOTOI $\mathrm{Y}$, INOUE S, HATTA $\mathrm{H}$, SATO $\mathrm{K}$, et al. Detection of rabies-specific antigens by egg yolk antibody (IgY) to the recombinant rabies virus proteins produced in Escherichia coli. Jpn. J. Infect. Dis. (2005).

37. CHIURCIU C, CHIURCIU V, OPORANU M, PǍTRACU IV et al. PC2 Ovotransferrin: Characterization and Alternative Immunotherapeutic Activity. Evidence-based Complement. Altern. Med. (2017).

38. ERHARD MH, KELLNER J, EICHELBERGER J, LÖSCH U. New aspects in oral immunoprophylaxis for the prevention of infectious diarrhoea of newborn calves - a field study with specific egg antibodies. Berl. Munch. Tierarztl. Wochenschr. (1993).

39. LEE SB, MINE Y, STEVENSON RMW. Effects of hen egg yolk immunoglobulin in passive protection of rainbow trout against Yersinia ruckeri. J. Agric. Food Chem. (2000).

40. MONY TJ, KWON HS, WON MK, KANG YM et al. Anti-urease immunoglobulin (IgY) from egg yolk prevents Helicobacter pylori infection in a mouse model. Food Agric. Immunol. (2019).

41. WALCZAK M, GRZYWA R, ŁUPICKA-SŁOWIK A, SKOREŃSKI $M$ et al. Method for generation of peptide-specific IgY antibodies directed to Staphylococcus aureus extracellular fibrinogen binding protein epitope. Biopolymers (2015).

42. CRISTE A. The use of the anti- sallmonela specific polyclonal antibodies isolated from hen eggs for inibiting the growing of the salmonella genus. Sci. Pap. Anim. Sci. Biotechnol. 40, 79-84, (2007).

43. SUI J, CAO, L, LIN H. Antibacterial activity of egg yolk antibody $(\operatorname{IgY})$ against Listeria monocytogenes and preliminary evaluation of its potential for food preservation. J. Sci. Food Agric. (2011).

44. HONKO AN, MIZEL SB. Effects of flagellin on innate and adaptive immunity. Immunol. Res. (2005).

45. SHIMAMOTO C, TOKIOKA S, HIRATA I, TANI H et al. Inhibition of Helicobacter pylori infection by orally administered yolk-derived anti-Helicobacter pylori antibody. Hepatogastroenterology. (2002).

46. MINE Y, ZHANG JW. The allergenicity of ovomucoid and the effect of its elimination from hen's egg white. J. Sci. Food Agric. (2001).

47. McCASKILL JL, RESSEL S, ALBER A, REDFORD J et al. Broad-Spectrum Inhibition of Respiratory Virus Infection by MicroRNA Mimics Targeting p38 MAPK Signaling. Mol. Ther. - Nucleic Acids (2017).

48. WALLACH MG, WEBBY RJ, ISLAM F, WALKDEN-BROWN $\mathrm{S}$ et al. Cross-protection of chicken immunoglobulin $\mathrm{Y}$ antibodies against H5N1 and H1N1 viruses passively administered in mice. Clin. Vaccine Immunol. (2011).
49. FU CY, HUANG H, WANG XM, LIU YG et al. Preparation and evaluation of anti-SARS coronavirus IgY from yolks of immunized SPF chickens. J. Virol. Methods (2006).

50. QUEIROZ-CASTRO VLD, DA COSTA EP; ALVES SVP, MACHADO-NEVES $M$ et al. A. Bovine herpesvirus 1 can cross the intact zona pellucida of bovine oocytes after artificial infection. PLoS One (2019).

51. WANG XZ, FAN B, LIU LG, HU XY, et al. In vitro inhibition of oral Candida albicans by chicken egg yolk antibody (IgY). Mycopathologia (2008).

52. GOTTSTEIN B, HEMMELER E. Egg yolk immunoglobulin $\mathrm{Y}$ as an alternative antibody in the serology of echinococcosis. Zeitschrift für Parasitenkd. Parasitol. Res. 1985.

53. HASSL A, ASPÖCK H, FLAMM H. Comparative studies on the purity and specificity of yolk immunoglobulin Y isolated from eggs laid by hens immunized with toxoplasma gondii antigen. Zentralblatt fur Bakteriol. Mikrobiol. und Hyg. - Abt. 1 Orig. A 1987.

54. JÚNIOR Á, SANTIAGO FM, SILVA MV, FERREIRA FB et al. Production, characterization and applications for toxoplasma gondii-specific polyclonal chicken egg yolk immunoglobulins. PLoS One (2012).

55. BARENCO PVC, LOURENÇO EV, CUNHA JP, ALMEIDA KC et al. Toxoplasma gondii $70 \mathrm{kDa}$ heat shock protein: Systemic detection is associated with the death of the parasites by the immune response and its increased expression in the brain is associated with parasite replication. PLoS One (2014).

56. XU JJ, REN CZ, WANG SS, LIU DD et al. Protection efficacy of multivalent egg yolk immunoglobulin against Eimeria tenella infection in Chickens. Iran. J. Parasitol. (2013).

57. SAMPAIO LCL, BALDISSERA MD, GRANDO TH, GRESSLER LT et al. Production, purification and therapeutic potential of egg yolk antibodies for treating Trypanosoma evansi infection. Vet. Parasitol. (2014).

58. GRANDO TH, BALDISSERA MD, DE SÁ MF, DO CARMO GM et al. Avian antibodies (IgY) against Trypanosoma cruzi: Purification and characterization studies. J. Immunol. Methods (2017).

59. MAYA DEVI C, VASANTHA BAI M, VIJAYAN LAL A, UMASHANKAR PR et al. An improved method for isolation of anti-viper venom antibodies from chicken egg yolk. J. Biochem. Biophys. Methods (2002).

60. CRISTE A, GEORGESCU B, CRISTE F, BOARU A, et al. The use of the anti-venom specific antibodies isolated from duck eggs for inactivation of the viper venom. Lucr. ştiinţifice Zooteh. și Biotehnol. 41, 49-52. (2008).

61. LEIVA CL, CANGELOSI A, MARICONDA V, FARACE M IgY-based antivenom against Bothrops alternatus: Production and neutralization efficacy. Toxicon (2019).

62. DE ALMEIDA CMC, DA SILVA CL, COUTO HP, ESCOCARD R et al. Development of process to produce polyvalent IgY antibodies anti-African snake venom. Toxicon (2008). 